\title{
CLASS ATTENDANCE AS A FACTOR AFFECTING ACADEMIC PERFORMANCE
}

\author{
Agita Doniña \\ Turiba University, Latvia \\ Karīna Svētiṇa \\ Turiba University, Latvia \\ Kristaps Svētin̄̌s \\ University of Latvia, Latvia
}

\begin{abstract}
The purpose of this paper is to investigate whether class attendance in higher education improves academic performance. The research has been performed among bachelor level (EQF 6) international students studying in English for a full-time degree in Latvia. The attendance is analysed for fall and spring semesters while the academic performance has been analysed in three categories - midterm exam grade, exam grade and the final assessment. Correlation as a research instrument has been applied. The research results reveal interconnectivity between the attendance of classes and the subsequent academic performance. The results of the correlation obtained have been discussed with a representative of Higher Education Export Association.
\end{abstract}

Keywords: academic performance, class attendance, correlation.

\section{Introduction}

Over the past decade, there have been increasing discussions on the importance of class attendance in higher education (Walker, Voce, Nicholls, Swift, \& Ahmed, 2014; Edwards \& Clinton, 2019). The authors have stated several reasons why class attendance would be important for the future success of students. Many researchers consider that with a shift of higher education towards E-learning, web-based learning, internet-based learning, online learning, or computer-assisted instruction, the importance of attending classes in the academic performance of students is diminished (Phillips \& Pharm, 2015; Vajoczki, Watt, Marquis, Liao, \& Vine, 2011; Morris, Swinnerton, \& Coop, 2019; Schnee et al., 2019).

There have been fewer studies on the importance of attending classes for students studying abroad. With an increase in international mobility, more and more students choose to study outside their home countries. According to OECD, more than 4.1 million tertiary-level students were enrolled outside their country of citizenship in 2010 (Education at a Glance 2012, 2012). For students who

(C) Rēzeknes Tehnologiju akadèmija, 2020

http://dx.doi.org/10.17770/sie2020vol6.5060 
choose to study abroad, the knowledge of languages is not the only essential issue. Studying in a foreign university requires students to adapt to the local study system and its requirements (Lan, 2018). Therefore, it can be assumed that class attendance is an extremely important factor for the successful performance of international students. Several authors, like Bijsmans and Schakel (2018), Jansen and Suhre (2010), Credé, Roch, and Kieszczynka (2010) have already pointed to this fact.

The aim of the research is to investigate whether class attendance in higher education improves academic performance. The research was conducted among international students studying at the Faculty of International Tourism of Turiba University (Latvia). The university has implemented an accurate class attendance register, where data are regularly recorded in the internal management system. The academic performance was analysed in 3 categories: midterm exam grade, exam grade and the final assessment.

\section{Class attendance and academic performance - theoretical approach}

A number of researches projects have addressed the impact of class attendance on academic performance internationally. As stated earlier, there is no consensus among researchers regarding an explicitly positive correlation between class attendance and academic performance. One of the researches, conducted in 2010 on Electronics Engineering course module, shows that class attendance is highly correlated to academic performance, despite the availability of online class notes (Nyamapfene, 2010). Researchers Paisey and Paisey (2004) provided a positive correlation between class attendance and academic performance in an accounting class in Scotland. They concluded that a positive correlation between attendance of classes and the subsequent academic performance was highly evident. Students appeared to have a realistic view of their attendance indicating that they believed that regular attendance would have a considerably greater effect on examination results as opposed to coursework performance (Paisey \& Paisey, 2004). A positive correlation between class attendance and academic performance was also found by researchers Schmuliana and Coetzee (2011), Thatcher, Fridjhon, and Cockcroft, (2007), Westerman, Perez-Batres, Coffey, and Pouder, (2011), Kassagnir, Bjerre-Nielsen, Mones, Lehmann, and Lassen (2017). Researchers Schmuliana and Coetzee (2011) found that the student who acquired the highest mark in the examination (88\%) had an overall attendance rate of $100 \%$ throughout the module. The student who acquired the lowest mark in the examination (8\%) had an overall attendance rate of $76 \%$ throughout the module. Researchers Irwin, Burnett, and McCarron (2018) observed a positive, and statistically significant interrelation between the attendance and the examination performance, especially in the coursework elements of the module. The 
attendance of the module across both year groups was approximately 80\% (Irwin, Burnett, \& McCarron, 2018).

At the same time, several other pieces of research clearly indicate that good academic performance is not always affected by class attendance. For example, a study conducted in Finland indicates that students, who for any reason study independently, have a good ability to proactively search for information and study independently (Lukkarinen, Koivukangas, \& Seppälä, 2016). The fact that attendance is not necessarily equivalent to learning and lectures are not always the best way to teach material has been researched by several authors (Brennan, Sharma, \& Munguia, 2019; Freeman et al., 2014; Kelly, 2012; Dolnicar et al., 2009).

\section{Reasons for lecture attendance}

Despite the fact that academic staff considers that attending classes contributes to the academic performance of students, the attendance is optional in many universities (Crede et al., 2010). There is a broad range of reasons, and the difficulty of attending lectures in large settings on a regular basis is named as one of them (Crede et al., 2010).

It is important not only to understand the consequences but also to find out the reasons for students choosing to miss classes. Two groups of reasons can be distinguished - one is related to students themselves, but another one - to lecturers and their teaching and assessing methods.

Despite the attempts of researchers to establish the most common causes of absence, it is absolutely certain that each student who misses classes has his or her own personal reason. Massingham and Herrington (2006) report that the most common causes of non-attendance and eventual withdrawal include sickness, being too busy and having to do paid work. Moreover, Field singles out genuine sickness as one of the key reasons for non-attendance (Field, 2012). Authors Paisey and Paisey (2004) point to the additional financial stress placed on students with the ever-increasing cost of their education and the subsequent need of students to acquire part-time jobs during term-time and vacations. The author reported that $21 \%$ of responses from 68 third-year students indicated that absence was a result of illness. He found that the most frequent response for missing classes was part-time work, with $34 \%$ of respondents stating this as a reason. Another reason was found by Massingham and Herrington. According to the researchers (Massingham \& Herrington, 2006), there are students who do not attend university for the enjoyment of the learning process, rather they focus on the end goal, which is to find a good job. Therefore, class attendance is not important to them. 
In the context of teaching, the main reason for attending classes from the point of view of a student is perceiving the class attendance as value for them. Value perceptions are based largely on the teaching process, the lecturer's competence and style of teaching. It may be that today's students are simply bored by the instructive approach they face in classes. Students are also particularly interested in information that will eventually help them in receiving a more positive assessment of their assignments and attend classes only for these reasons.

Technologies also play an important role in university - student relations. With the availability of a broad range of information resources, the value of classes decreases. Field states that issues such as boring content and information already being available, are recorded as prominent motives for non-attendance (Field, 2012).

Without denying the importance of all the reasons mentioned above, however, one of the most frequent reasons still is the paid work of students carried out in parallel with studies.

\section{Paid employment and its impact on studies}

Recent reports indicate that there is a significant share of students who work regularly throughout the whole study period. Research shows that $72.5 \%$ of Australian university students have paid employment during the semester, working an average of 15 hours per week (McInnins \& Hartlet, 2002). Around $50 \%$ of students are engaged in paid jobs during the lecture period in Estonia and Germany, Latvia, Switzerland, Czech Republic, Austria, the Netherlands and Norway (Masevičiūtè, Šaukeckienè, \& Ozolinčiūtė, 2018).

Moreover, $50 \%$ of students state that without a paid job, they could not afford to study. Having a paid job during studies means that students are demanding more flexibility in the way they study (Massingham \& Herrington, 2006).

There is a clear concern for policy-makers and students that part-time or sometimes even full-time employment will have a deleterious impact on the study and academic attainment. Having a job in term-time is not just an academic problem, it has implications for access policies, states Robin Humphrey (2001). In the Barke, Braidford, and Houston (2002) study the students were asked to assess the impact that part-time work had on their studies. The majority (57.1\%) of working students perceived that employment had no effect upon their academic performance, $42.9 \%$ of students felt that their term-time job did have a deleterious effect on their academic performance. $35.6 \%$ of working students admitted missing time-tabled sessions as a result of their work commitments. Comparable analyses of academic performance of working and non-working students, show than students without employment showed significantly better results in comparison with the median employed student (Barke, Braidford, \& Houston, 
2002). Humphrey (2001) found that engaging in term-time employment had important consequences for social experiences and in the academic performance of students. Students who were employed during the academic year had a 3 per cent lower mark on an end-of-year on average in comparison to students who could concentrate on studies only (Humphrey, 2001). However, by researching the different type of students' employed, Yanbarisova (2015) found that only nonprofessional full-time employed students felt the negative effects of employment on their academic performance. Other strategies of student employment showed no statistically significant effect on academic performance.

Authors of the discussion paper 'Does Student Work Really Affect Educational Outcomes? A Review of the Literature', having analysed the results of a number of authors' studies, found mainly a negative effect of student employment on academic performance, and hence that student work appeared to be a substitute for education. In particular, studies report that more intensive working schemes yield worse educational outcomes (Neyt, Omey, Verhaest, \& Baert, 2017).

To summarize, the authors conclude that there are different reasons for students not attending classes, including a paid job. In addition, there is an increasing trend for more and more students to work in parallel with their studies. Results on the impact of class attendance on academic results show mixed results and further research should be conducted.

\section{Background}

Latvian higher education institutions are attracting international students in order to internationalise the overall study and research environment, to meet international recognition and to compensate the unstable domestic students' market. The biggest drop of domestic students took place in 2009 when the number of first-year students decreased by $26 \%$ compared to the previous year and the absolute number of students in Latvian higher education institutions decreased by $10 \%$. Since then, Latvia has been actively involved in the internationalization process (Auers \& Gubins, 2016).

In 2018 the total number of full-time international students studying in all higher education institutions in Latvia reached 8,380, representing $10 \%$ of all students of higher education institutions and colleges in Latvia. In comparison, there were 7.563 (9\%) international students in 2017 and 8.137 (10\%) in 2016 (Pārskats par Latvijas augstāko izglītību, 2016, 2017; Pārskats par Latvijas augstāko izglīî̄bu, 2017, 2018; Pārskats par Latvijas augstāko izglîtību, 2018, 2019).

The research sample involves professional bachelor students of Turiba University (Latvia). Turiba University is the biggest private university in Latvia, 
established in 1993. First full-time study programme in English, established for attracting international students was opened in 2003. At the moment, there are 3,333 students studying in one of the 24 study programmes. Out of them, there are totally 829 (as on 01.10.2019) permanent international students at Turiba University. More than $45 \%$ of the international students - 249 - study in the Tourism and Hospitality management study programme. In general, Turiba University holds the $4^{\text {th }}$ position in terms of the number of international students enrolled (Turiba University, 2019).

\section{The methodology}

The purpose of this research is to investigate whether class attendance in higher education improves academic performance.

The research sample involves professional bachelor students of Tourism and Hospitality Management study programme of Turiba University (Latvia). Accurate and regular attendance registers are required at Turiba University and the data acquired are regularly recorded in the internal management system. Data were analysed for 3 semesters in the academic years 2018/2019 and 2019/2020. Overall, data from 21 study courses (Table No.1) were analysed. The attendance was analysed purposely among first-year students who still held the highest motives of attending classes.

Attendance was checked on a regular basis for every study course. Classes comprised a mix of lectures and seminars. The attendance was coded as " 1 " if students attend the class and "0" if they did not. No information was collected regarding the reasons for absence. Attendance was categorized in percentages at 10 groups (for example 0\%-10\%, 10\%-20\%...80\%-90\%, 90\%-100\%) for correlation analysis.

The maximum number of classes, planned for a study course, is calculated based on the requirements established by law (Regulations on the second level professional higher education state standard, 2014), which define that there should be at least 16 contact hours per 1 credit point.

Academic performance was analysed in 3 categories: a midterm exam, an exam and the final assessment. For midterm exam 1025 and for exam 891 students` grades have been included for analyses.

The total assessment is calculated on the basis of a value assigned to each midterm exam grade and the exam grade (summative scoring system). All data are analysed only in an aggregated form without evaluating the performance of a particular student.

According to the Regulations on the second level professional higher education state standard (2014) students' assessment is carried out on a 10 point scale ("10" - with distinction and " 1 " - unsatisfactory), where grade "4" (almost 
satisfactory) is the last credited grade "pass" in Latvia. Academic performance of students analysed in absolute grades according to the legislation of Latvia.

The quantitative approach to the study was selected as appropriate research to explain the relationship among variables (Creswell, 2005).

The study was conducted in 2 stages: 1) context analysis, 2) empirical study. The empirical study was developed by a descriptive analysis of students' attendance and the attendance and academic performance correlation analysis (Pearson quotient). Correlation designs are procedures in quantitative research in which researchers measure the degree of relationship between two or more variables using correlation analysis (Creswell, 2005). The degree of relationship indicates whether one variable can predict another.

The quantitative data analysis software MsExcel 2016 was applied for data processing. To calculate the correlation in MsExcel Correlation formula "Correl (If)" is used as argument choosing - study course and category of assessment (Slavio, 2017).

The descriptive analysis is made for class attendance (in \%) analysis toward midterm exam grade and exam grade. The average level of attendance (\%) per study courses was analysed. It might be concluded that significant difference does exist between attendance of study courses and midterm exam $(\mathrm{r}=4.65, \mathrm{p}=0.00)$, exam grade $(\mathrm{r}=2.43, \mathrm{p}=0.00)$ and final assessment $(\mathrm{r}=2.47, \mathrm{p}=0.00)$. Data are statistically significant at confidence level 0.95 . There is no week correlation between student attendance and midterm grade $(\mathrm{R}=0.40)$, exam grade $(\mathrm{R}=0.23)$ and final assessment $(\mathrm{R}=0.24)$. $\mathrm{R}$ Square $=16 \%$ for midterm grade, $5 \%$ for exam grade and $6 \%$ for final assessment (explained by variability of attendance in \%, which is not satisfactory result for class attendance).

The results of the correlation obtained have been discussed with a representative of Higher Education Export Association.

\section{Results}

Research indicates a highly diverse attendance of classes in different study courses. The highest average attendance is for English 2, where the observed average attendance reached $81.97 \%$. The lowest attendance was recorded at Civil Defense classes, where an average only $7.69 \%$ attended classes. According to the sources assessed previously, as well as to the opinion of representative of Higher Education Export Association, the motivation to attend classes can be affected by the overall number of students in the class (e.g., in the Civil Defense classes there are around 150 students, which is the exact opposite to the small language classes)

Per all study courses at $10 \%$ attendance, the midterm exam grade " 4 " earns $5.17 \%$ of the total number of students (exam grade $3.93 \%$ students). It can be 
concluded that a successful assessment can be achieved by attending even the minimum number of classes.

On the other hand, higher midterm exam and exam grades ranging from " 5 " to " 10 " can be acquired with the attendance of 50\%-70\% of all classes. $29 \%$ of students fall in this category in the case of the midterm exam grade (26.6\% of students in the case of the exam grade). In Higher Education Export Association believes that motivation to get better grades and more to attend lessons appears in later courses. As well as important motivation for students is possibility to obtain scholarships.

It can be concluded that there exists a clear regularity and grades for most students will increase with a 60\%-70\% attendance of classes. A 90\%-100\% attendance is reached by $2.93 \%$ of the total number of students who have passed the midterm exam and exam. This indicates that by attending $90 \%-100 \%$ of all classes there is only a $0.49 \%$ chance of getting the highest grade " 10 " in the midterm exam (and $0.34 \%$ in the case of the exam). The students who attended $70 \%$ of all classes did not fail their midterm exams. In the case of the exam, such regularity does not exist. Negative grade " 3 - not passed" was received by $0.11 \%$ of students who attended $90 \%-100 \%$ of all classes.

Table 1 depicts the correlation between academic performance and attendance per study courses in the years 2018 and 2019. The average attendance in \% per all study courses in 2018 and in 2019 is $47.05 \%$. Table 1 reflects the analysis of the average grades and attendance per study courses. The lowest average grade for the midterm exam is " 5.75 " in the study course Hospitality and Customer Service and the highest average grade of "8.4" is in study course Catering Service", while the average attendance of both study courses is rather equal.

A conclusion can be drawn that attendance does not affect academic performance. The lowest average grade for the exam is " 4.80 " in study course Travel Agencies and Information Systems while the highest is "7.03" in the study course Professional terminology 2, which in this case could be explained by a gap of attendance between courses.

Therefore, it can be concluded that higher attendance equals higher grade. The highest final assessment is "7.20" in the study course Information Technologies, while the lowest average grade is "5.00" in study course Travel Agencies and Information Systems. However, in this case, there is no regularity, since the average attendance of both courses average is among the lowest compared to other study courses.

Learning the average grades and the average attendance per individual study courses provides for the opportunity of calculating Pearson correlation. Table 1 reflects the results of stemming from the correlation, formula used "Correl (If)" as argument changing each time with a different study course. 
SOCIETY. INTEGRATION. EDUCATION

Proceedings of the International Scientific Conference. Volume VI, May $22^{\text {th }}-23^{\text {th }}, 2020.578-594$

Table 1 Correlation between academic performance and attendance per study courses (created by the authors)

\begin{tabular}{|c|c|c|c|c|c|c|c|}
\hline \multirow[b]{2}{*}{ Study courses } & \multicolumn{4}{|c|}{ Average } & \multicolumn{3}{|c|}{$\begin{array}{l}\text { Correlation (r) between academic } \\
\text { performance and attendance }\end{array}$} \\
\hline & $\begin{array}{c}\text { Midterm } \\
\text { exam grade }\end{array}$ & $\begin{array}{l}\text { Exam } \\
\text { grade }\end{array}$ & $\begin{array}{c}\text { Final } \\
\text { assesment }\end{array}$ & $\begin{array}{c}\text { Attendance } \\
(\%)\end{array}$ & $\begin{array}{l}\text { Midterm } \\
\text { exam grade }\end{array}$ & Exam grade & $\begin{array}{c}\text { Final } \\
\text { assessment }\end{array}$ \\
\hline Civil Defence & 6,01 & 4,97 & 5,44 & 7,69 & 0.27 & 0.10 & 0.09 \\
\hline Food and Beverage Operation & 7,56 & 5,91 & 7,12 & 52,06 & 0.15 & $(0.02)$ & $(0.02)$ \\
\hline Catering Service & 8,04 & 6,43 & 7,08 & 46,70 & 0.53 & 0,33 & 0.49 \\
\hline Research Methods & 6,2 & 6,4 & 6,13 & 55,00 & 0.57 & 0,52 & 0.55 \\
\hline Introduction into Tourism & 7,15 & 6,57 & 6,79 & 58,93 & 0.15 & 0,29 & 0.28 \\
\hline Information Technologies & 7,33 & 6,68 & 7,2 & 27,06 & 0.09 & $(0.05)$ & 0.06 \\
\hline English 1 & 6,36 & 5,89 & 6,23 & 50,21 & 0.14 & 0,17 & 0.23 \\
\hline English 2 & 6,23 & 6,77 & 6,46 & 81,97 & 0.39 & 0,43 & 0.43 \\
\hline $\begin{array}{l}\text { Professional terminology (German / French } \\
\text { / Spanish / Russian) } 2\end{array}$ & 6,73 & 7,03 & 6,87 & 72,92 & 0.29 & 0,49 & 0.37 \\
\hline $\begin{array}{l}\text { Professional terminology (German / French } \\
\text { / Spanish / Russian) } 1\end{array}$ & 6,88 & 6,75 & 7,02 & 48,96 & 0.23 & 0,2 & 0.19 \\
\hline Travel Agencies and Information Systems & 6,87 & 4,8 & 5 & 25,00 & 0.35 & $(0.13)$ & $(0.13)$ \\
\hline Tourism Geography & 6,88 & 6,28 & 6,74 & 46,66 & 0.18 & $(0.06)$ & $(0.01)$ \\
\hline Hospitality and Customer Service & 5,75 & 6,15 & 6,12 & 44,68 & 0.25 & 0.22 & 0.22 \\
\hline Hotel Department Management & 6,46 & 5,31 & 6,06 & 40,82 & 0.58 & 0.50 & 0.46 \\
\hline
\end{tabular}

The correlation can be observed for the study course Hotel Department Management for midterm exam grade $(\mathrm{r}=0.58)$, for the exam grade $(\mathrm{r}=0,50)$ and for the final assessment $(\mathrm{r}=0.46)$. The correlation between attendance and grades has been observed in the study course Research Methods indication midterm exam $(\mathrm{r}=0.57)$, exam ( $\mathrm{r}=0.52)$ and final assessment $(\mathrm{r}=0.55)$ correlation. In the study course, Food and Beverage Operation the correlation have been observed for midterm exam grade and attendance $(\mathrm{r}=0.53)$.

It is clear that more thorough results could be gained if the academic performance per study courses were addressed individually per each study course`s attendance rates.

Table 2 reflects the Pearson correlation between the academic performance in 3 categories (the midterm exam grade, the exam grade, the final assessment) and the total attendance. It was found that there was not a particularly strong correlation between the total attendance and the total academic performance (Pearson's correlation coefficient, $r=0.47, r=0.42, r=0.40$ ). Therefore, the attendance and the academic performance for each study course shown in Table 2 will be analysed. 
Table 2 Correlation between total academic performance and total attendance (created by the authors)

\begin{tabular}{|c|c|c|c|}
\hline & \multicolumn{3}{|c|}{$\begin{array}{l}\text { Pearson correlation (r) between total academic performance } \\
\text { and total attendance }\end{array}$} \\
\hline & $\begin{array}{l}\text { Midterm grade } \\
\text { exam }\end{array}$ & Exam grade & Final assessment \\
\hline Attendance & $\mathrm{r}=0.47$ & $\mathrm{r}=0.42$ & $r=0.40$ \\
\hline Number of students & 1025 & 891 & 957 \\
\hline
\end{tabular}

Table 3 provides information on Pearson correlation analysis regarding Midterm exam grade per attendance levels (from 0\%-100\%) per study courses. The correlation is strong for the study course Introduction into Tourism at attendance $10 \%-20 \%(\mathrm{r}=1)$ and at attendance $30 \%-40 \%(\mathrm{r}=0.96)$. The correlation is also strong for the study course English 2 at attendance 50\%-60\% (r=1). A strong correlation $(\mathrm{r}=1)$ exists for the study course Research Methods at attendance $30 \%-40 \%$.

Table 3 Correlation - Midterm exam grade per attendance (\%) per study course (created by the authors)

\begin{tabular}{|c|c|c|c|c|c|c|c|c|c|c|}
\hline \multirow[b]{2}{*}{ Study courses } & \multicolumn{10}{|c|}{ Attendance (\%) } \\
\hline & 0\%-10\% & $10-20 \%$ & $20 \%-30 \%$ & $30 \%-40 \%$ & $40 \%-50 \%$ & $50 \%-60 \%$ & $60 \%-70 \%$ & $70 \%-80 \%$ & $80 \%-90 \%$ & $90 \%-100 \%$ \\
\hline Civil Defence & $\mathrm{n} / \mathrm{c}$ & 0.89 & $\mathrm{n} / \mathrm{c}$ & $\mathrm{n} / \mathrm{a}$ & $\mathrm{n} / \mathrm{a}$ & $\mathrm{n} / \mathrm{a}$ & $\mathrm{n} / \mathrm{a}$ & $\mathrm{n} / \mathrm{a}$ & $\mathrm{n} / \mathrm{a}$ & $\mathrm{n} / \mathrm{a}$ \\
\hline Food and Beverage Operation & $\mathrm{n} / \mathrm{c}$ & $\mathrm{n} / \mathrm{a}$ & $(0.45)$ & 0.68 & $(0.50)$ & 0.02 & $(0.12)$ & $(0.55)$ & 0.68 & $\mathrm{n} / \mathrm{a}$ \\
\hline Catering Service & $\mathrm{n} / \mathrm{c}$ & 0.76 & $\mathrm{n} / \mathrm{c}$ & 0.37 & $\mathrm{n} / \mathrm{c}$ & 0.37 & $(0.70)$ & $n / c$ & $\mathrm{n} / \mathrm{c}$ & $\mathrm{n} / \mathrm{a}$ \\
\hline Research Methods & $\mathrm{n} / \mathrm{a}$ & $\mathrm{n} / \mathrm{c}$ & n/a & 1.00 & $\mathrm{n} / \mathrm{a}$ & $(0.37)$ & $(0.58)$ & $\mathrm{n} / \mathrm{a}$ & $\mathrm{n} / \mathrm{c}$ & $\mathrm{n} / \mathrm{a}$ \\
\hline Introduction into Tourism & 0.65 & 1.00 & $(0.04)$ & 0.96 & $(0.79)$ & 0.00 & 0.24 & 0.31 & $(0.06)$ & n/a \\
\hline Information Technologies & 0.06 & $(0.75)$ & $\mathrm{n} / \mathrm{c}$ & 0.01 & $\mathrm{n} / \mathrm{c}$ & 0.26 & 0.72 & $(0.13)$ & $\mathrm{n} / \mathrm{c}$ & $\mathrm{n} / \mathrm{a}$ \\
\hline English 1 & 0.65 & 0.65 & $\mathrm{n} / \mathrm{c}$ & 0.02 & $\mathrm{n} / \mathrm{c}$ & 0.05 & 0.10 & $\mathrm{n} / \mathrm{c}$ & $\mathrm{n} / \mathrm{c}$ & $\mathrm{n} / \mathrm{a}$ \\
\hline English 2 & $\mathrm{n} / \mathrm{a}$ & $\mathrm{n} / \mathrm{c}$ & $\mathrm{n} / \mathrm{a}$ & $\mathrm{n} / \mathrm{c}$ & $\mathrm{n} / \mathrm{c}$ & 1.00 & $\mathrm{n} / \mathrm{c}$ & $\mathrm{n} / \mathrm{c}$ & $(1.00)$ & $\mathrm{n} / \mathrm{c}$ \\
\hline $\begin{array}{l}\text { Professional terminology (German / French / } \\
\text { Spanish / Russian) } 2\end{array}$ & $\mathrm{n} / \mathrm{c}$ & $(1.00)$ & $\mathrm{n} / \mathrm{a}$ & $\mathrm{n} / \mathrm{c}$ & $\mathrm{n} / \mathrm{a}$ & 0.00 & $(0.72)$ & $\mathrm{n} / \mathrm{c}$ & $(0.28)$ & 0.32 \\
\hline $\begin{array}{l}\text { Professional terminology (German / French / } \\
\text { Spanish / Russian) } 1\end{array}$ & $(0.32)$ & 0.01 & $\mathrm{n} / \mathrm{c}$ & 0.66 & $\mathrm{n} / \mathrm{c}$ & $(0.08)$ & 0.22 & $\mathrm{n} / \mathrm{c}$ & $\mathrm{n} / \mathrm{c}$ & 0.13 \\
\hline Travel Agencies and Information Systems & $\mathrm{n} / \mathrm{a}$ & $\mathrm{n} / \mathrm{a}$ & 0.58 & $\mathrm{n} / \mathrm{a}$ & $\mathrm{n} / \mathrm{a}$ & $\mathrm{n} / \mathrm{a}$ & $\mathrm{n} / \mathrm{a}$ & $\mathrm{n} / \mathrm{a}$ & $\mathrm{n} / \mathrm{a}$ & $\mathrm{n} / \mathrm{a}$ \\
\hline Tourism Geography & $\mathrm{n} / \mathrm{c}$ & $\mathrm{n} / \mathrm{c}$ & $\mathrm{n} / \mathrm{c}$ & 0.49 & $\mathrm{n} / \mathrm{c}$ & 0.22 & $\mathrm{n} / \mathrm{c}$ & $\mathrm{n} / \mathrm{c}$ & $\mathrm{n} / \mathrm{a}$ & $\mathrm{n} / \mathrm{a}$ \\
\hline Hospitality and Customer Service & 0.87 & $\mathrm{n} / \mathrm{c}$ & $(1.00)$ & $(0.16)$ & $(0.14)$ & 0.31 & $\mathrm{n} / \mathrm{c}$ & $\mathrm{n} / \mathrm{c}$ & $\mathrm{n} / \mathrm{a}$ & $\mathrm{n} / \mathrm{a}$ \\
\hline Hotel Department Management & $\mathrm{n} / \mathrm{a}$ & $\mathrm{n} / \mathrm{a}$ & $\mathrm{n} / \mathrm{c}$ & 0.20 & $\mathrm{n} / \mathrm{c}$ & $\mathrm{n} / \mathrm{c}$ & $\mathrm{n} / \mathrm{a}$ & $\mathrm{n} / \mathrm{a}$ & $\mathrm{n} / \mathrm{a}$ & $\mathrm{n} / \mathrm{a}$ \\
\hline
\end{tabular}

A negative correlation, represented in brackets, could mean that with the increase of the value of one variable (i.e. the attendance), the value of the other variable decreases (grade). This phenomenon is mainly observed at 60\%-70\% attendance and at some point, has been observed for 9 study courses (out of 14). 
Based on results reflected in Table 3, it can be concluded that attendance strongly correlates with academic performance in the midterm exam grade category in 11 (out of 14) study courses and at least in one of the attendance levels (assuming that strong correlation is $\mathrm{r} \geq 0.50$ ).

Table 4 also shows that the correlation was quite high between attendance and academic performance (in the category of exam grade) in 11 study courses out of 14 courses at least in one of the attendance levels (assuming that a strong correlation is $r \geq 0,50$ ). Table 4 shows that the greatest correlation is for the study course English $2(\mathrm{r}=1)$ both at attendance 50\%-60\% and at attendance 80\%-90\%.

An excellent correlation is reflected in the study course Hotel Department Management ( $\mathrm{r}=1)$ at 20\%-30\% attendance and the study course Food and Beverage Operation $(\mathrm{r}=0,93)$ at attendance $80 \%-90 \%$.

A negative correlation is mainly observed at $50 \%-60 \%$ attendance and at some point, has been observed for 10 study courses (out of 14). This fact has to be taken into account by educators for the purpose of designing meaningful, interesting and stimulating study courses and for promoting the achievement higher grades.

Table 5 reflects the correlation between the final assessment per attendance levels (\%) per study courses. It might be concluded that there was a clear relationship between the two factors in the study course English $2(\mathrm{r}=1)$ both at $50 \%-60 \%$ and at $80 \%-90 \%$ level of attendance. The correlation exists ( $\mathrm{r}=1)$ for the study course Hotel Department Management at attendance 20\%-30\%.

Table 4 Correlation - Exam grade per attendance (\%) per study course (created by the authors)

\begin{tabular}{|c|c|c|c|c|c|c|c|c|c|c|}
\hline \multirow[b]{2}{*}{ Study courses } & \multicolumn{10}{|c|}{ Attendance (\%) } \\
\hline & 0\%-10\% & $10-20 \%$ & $20 \%-30 \%$ & $3 \%-40 \%$ & $40 \%-50 \%$ & $50 \%-60 \%$ & $60 \%-70 \%$ & $70 \%-80 \%$ & $80 \%-90 \%$ & $90 \%-100 \%$ \\
\hline Civil Defence & $\mathrm{n} / \mathrm{c}$ & 0.71 & $\mathrm{n} / \mathrm{c}$ & $\mathrm{n} / \mathrm{a}$ & $\mathrm{n} / \mathrm{a}$ & $\mathrm{n} / \mathrm{a}$ & $\mathrm{n} / \mathrm{a}$ & $\mathrm{n} / \mathrm{a}$ & $\mathrm{n} / \mathrm{a}$ & $\mathrm{n} / \mathrm{a}$ \\
\hline Food and Beverage Operation & $\mathrm{n} / \mathrm{c}$ & $\mathrm{n} / \mathrm{a}$ & 0.13 & 0.32 & $(0.15)$ & $(0.08)$ & $(0.21)$ & $(0.39)$ & 0.93 & $\mathrm{n} / \mathrm{a}$ \\
\hline Catering Service & $\mathrm{n} / \mathrm{c}$ & 0.50 & $\mathrm{n} / \mathrm{c}$ & 0.24 & $\mathrm{n} / \mathrm{c}$ & $(0.26)$ & $(0.33)$ & $\mathrm{n} / \mathrm{c}$ & $\mathrm{n} / \mathrm{c}$ & $\mathrm{n} / \mathrm{a}$ \\
\hline Research Methods & $\mathrm{n} / \mathrm{a}$ & $\mathrm{n} / \mathrm{c}$ & $\mathrm{n} / \mathrm{a}$ & $\mathrm{n} / \mathrm{c}$ & $\mathrm{n} / \mathrm{a}$ & $(0.89)$ & 0.58 & $\mathrm{n} / \mathrm{a}$ & $\mathrm{n} / \mathrm{c}$ & $\mathrm{n} / \mathrm{a}$ \\
\hline Introduction into Tourism & $(1.00)$ & $(1.00)$ & $(0.12)$ & 0.78 & $(0.72)$ & 0.04 & 0.07 & 0.12 & 0.03 & $\mathrm{n} / \mathrm{a}$ \\
\hline Information Technologies & 0.02 & $(0.89)$ & $(0.93)$ & $(0.04)$ & $\mathrm{n} / \mathrm{c}$ & 0.38 & 0.13 & $(0.33)$ & $\mathrm{n} / \mathrm{c}$ & $\mathrm{n} / \mathrm{a}$ \\
\hline English 1 & 0.72 & 0.28 & $\mathrm{n} / \mathrm{c}$ & 0.08 & $\mathrm{n} / \mathrm{c}$ & 0.07 & 0.32 & $\mathrm{n} / \mathrm{c}$ & $\mathrm{n} / \mathrm{c}$ & $\mathrm{n} / \mathrm{a}$ \\
\hline English 2 & $\mathrm{n} / \mathrm{a}$ & $\mathrm{n} / \mathrm{c}$ & $\mathrm{n} / \mathrm{a}$ & $\mathrm{n} / \mathrm{c}$ & $\mathrm{n} / \mathrm{c}$ & 1.00 & $\mathrm{n} / \mathrm{c}$ & $\mathrm{n} / \mathrm{c}$ & 1.00 & $\mathrm{n} / \mathrm{c}$ \\
\hline $\begin{array}{l}\text { Professional terminology (German / French / } \\
\text { Spanish / Russian) } 2\end{array}$ & $\mathrm{n} / \mathrm{c}$ & $(1.00)$ & $\mathrm{n} / \mathrm{a}$ & $\mathrm{n} / \mathrm{c}$ & $\mathrm{n} / \mathrm{a}$ & $(0.58)$ & 0.08 & $\mathrm{n} / \mathrm{c}$ & $(0.49)$ & 0.21 \\
\hline $\begin{array}{l}\text { Professional terminology (German / French / } \\
\text { Spanish / Russian) } 1\end{array}$ & 0.44 & $(0.44)$ & $\mathrm{n} / \mathrm{c}$ & 0.51 & $\mathrm{n} / \mathrm{c}$ & 0.05 & 0.16 & $\mathrm{n} / \mathrm{c}$ & $\mathrm{n} / \mathrm{c}$ & 0.12 \\
\hline Travel Agencies and Information Systems & $\mathrm{n} / \mathrm{a}$ & $\mathrm{n} / \mathrm{a}$ & $(0.13)$ & $\mathrm{n} / \mathrm{a}$ & $\mathrm{n} / \mathrm{a}$ & $\mathrm{n} / \mathrm{a}$ & $\mathrm{n} / \mathrm{a}$ & $\mathrm{n} / \mathrm{a}$ & $\mathrm{n} / \mathrm{a}$ & $\mathrm{n} / \mathrm{a}$ \\
\hline Tourism Geography & $\mathrm{n} / \mathrm{c}$ & $\mathrm{n} / \mathrm{c}$ & $\mathrm{n} / \mathrm{c}$ & 0.70 & $\mathrm{n} / \mathrm{c}$ & $(0.17)$ & $\mathrm{n} / \mathrm{c}$ & $\mathrm{n} / \mathrm{c}$ & $\mathrm{n} / \mathrm{a}$ & $\mathrm{n} / \mathrm{a}$ \\
\hline Hospitality and Customer Service & 0.57 & $\mathrm{n} / \mathrm{c}$ & $(1.00)$ & $(0.12)$ & $(0.40)$ & $(0.20)$ & $\mathrm{n} / \mathrm{c}$ & $\mathrm{n} / \mathrm{c}$ & n/a & $\mathrm{n} / \mathrm{a}$ \\
\hline Hotel Department Management & $\mathrm{n} / \mathrm{a}$ & $\mathrm{n} / \mathrm{a}$ & 1.00 & $\mathrm{n} / \mathrm{c}$ & $\mathrm{n} / \mathrm{c}$ & $\mathrm{n} / \mathrm{c}$ & $\mathrm{n} / \mathrm{a}$ & $\mathrm{n} / \mathrm{a}$ & $\mathrm{n} / \mathrm{a}$ & $\mathrm{n} / \mathrm{a}$ \\
\hline $\begin{array}{l}\mathrm{n} / \mathrm{c}=\text { date is uncorrelated } \\
\mathrm{n} / \mathrm{a}=\text { no student has attended the course }\end{array}$ & ran & endar & & & & & & & & \\
\hline
\end{tabular}


A negative correlation is observed again at attendance $60 \%-70 \%$ and at some point, has been observed for 9 study courses (out of 14). The possible explanation is that in some courses the attendance is not a decisive factor for acquiring higher academic performance indicators.

Based on results reflected in Table 5 it can be concluded that attendance strongly correlates with academic performance in the category Final assessment in 11 (out of 14) study courses at least in one of the attendance levels (assuming that strong correlation is $r \geq 0,50$ ).

Moreover, it can be concluded that study course English 2 has an equal correlation ( $\mathrm{r}=1)$ among all 3-grade categories at the attendance level 50\%-60\%. Since students are from many countries where their mother language is not English and the studies are in the English language, attending English classes might be one of the factors for a higher correlation for attendance and academic performance. In addition, English 1 and English 2 have almost no negative correlation among 3-grade categories (with the exception of the midterm exam grade for English 2 at $80 \%-90 \%$ attendance).

\section{Table 5 Correlation - Final assessment per attendance (\%) per study course} (created by the authors)

\begin{tabular}{|l|c|c|c|c|c|c|c|c|c|c|c|}
\hline \multirow{2}{*}{ Study courses } & \multicolumn{10}{|c|}{ Attendance (\%) } \\
\cline { 2 - 12 } & $0 \%-10 \%$ & $10-20 \%$ & $20 \%-30 \%$ & $3 \%-40 \%$ & $40 \%-50 \%$ & $50 \%-60 \%$ & $60 \%-70 \%$ & $70 \%-80 \%$ & $80 \%-90 \%$ & $90 \%-100 \%$ \\
\hline Civil Defence & $\mathrm{n} / \mathrm{c}$ & $\mathbf{0 . 7 7}$ & $\mathrm{n} / \mathrm{c}$ & $\mathrm{n} / \mathrm{a}$ & $\mathrm{n} / \mathrm{a}$ & $\mathrm{n} / \mathrm{a}$ & $\mathrm{n} / \mathrm{a}$ & $\mathrm{n} / \mathrm{a}$ & $\mathrm{n} / \mathrm{a}$ & $\mathrm{n} / \mathrm{a}$ \\
\hline Food and Beverage Operation & $\mathrm{n} / \mathrm{c}$ & $\mathrm{n} / \mathrm{a}$ & 0.34 & $\mathbf{0 . 6 2}$ & $(0.35)$ & $(0.05)$ & $(0.18)$ & $(0.58)$ & 0.33 & $\mathrm{n} / \mathrm{a}$ \\
\hline Catering Service & $\mathrm{n} / \mathrm{c}$ & $\mathbf{0 . 5 0}$ & $\mathrm{n} / \mathrm{c}$ & 0.25 & $\mathrm{n} / \mathrm{c}$ & 0.09 & $(0.62)$ & $\mathrm{n} / \mathrm{c}$ & $\mathrm{n} / \mathrm{c}$ & $\mathrm{n} / \mathrm{a}$ \\
\hline Research Methods & $\mathrm{n} / \mathrm{a}$ & $\mathrm{n} / \mathrm{c}$ & $\mathrm{n} / \mathrm{a}$ & $\mathrm{n} / \mathrm{c}$ & $\mathrm{n} / \mathrm{a}$ & $(0.71)$ & $(0.58)$ & $\mathrm{n} / \mathrm{a}$ & $\mathrm{n} / \mathrm{c}$ & $\mathrm{n} / \mathrm{a}$ \\
\hline Introduction into Tourism & $\mathrm{n} / \mathrm{c}$ & $(1.00)$ & $(0.06)$ & $\mathbf{0 . 8 7}$ & $(0.72)$ & 0.01 & 0.30 & 0.18 & $(0.17)$ & $\mathrm{n} / \mathrm{a}$ \\
\hline Information Technologies & $\mathrm{n} / \mathrm{c}$ & $(0.85)$ & $(0.33)$ & 0.01 & $\mathrm{n} / \mathrm{c}$ & $\mathbf{0 . 6 0}$ & 0.42 & $(0.29)$ & $\mathrm{n} / \mathrm{c}$ & $\mathrm{n} / \mathrm{a}$ \\
\hline English 1 & 0.65 & $\mathbf{0 . 5 0}$ & $\mathrm{n} / \mathrm{c}$ & 0.12 & $\mathrm{n} / \mathrm{c}$ & 0.06 & 0.20 & $\mathrm{n} / \mathrm{c}$ & $\mathrm{n} / \mathrm{c}$ & $\mathrm{n} / \mathrm{a}$ \\
\hline English 2 & 0.65 & $\mathrm{n} / \mathrm{c}$ & $\mathrm{n} / \mathrm{a}$ & $\mathrm{n} / \mathrm{c}$ & $\mathrm{n} / \mathrm{c}$ & $\mathbf{1 . 0 0}$ & $\mathrm{n} / \mathrm{c}$ & $\mathrm{n} / \mathrm{c}$ & $\mathbf{1 . 0 0}$ & $\mathrm{n} / \mathrm{c}$ \\
\hline $\begin{array}{l}\text { Professional terminology (German / French / } \\
\text { Spanish / Russian) 2 }\end{array}$ & 0.65 & $(1.00)$ & $\mathrm{n} / \mathrm{a}$ & $\mathrm{n} / \mathrm{c}$ & $\mathrm{n} / \mathrm{a}$ & $(0.58)$ & $(0.25)$ & $\mathrm{n} / \mathrm{c}$ & 0.44 & 0.20 \\
\hline $\begin{array}{l}\text { Professional terminology (German / French / } \\
\text { Spanish / Russian) 1 }\end{array}$ & 0.65 & $(0.12)$ & $\mathrm{n} / \mathrm{c}$ & $\mathbf{0 . 6 1}$ & $\mathrm{n} / \mathrm{c}$ & 0.00 & 0.19 & $\mathrm{n} / \mathrm{c}$ & $\mathrm{n} / \mathrm{c}$ & 0.13 \\
\hline Travel Agencies and Information Systems & 0.65 & $\mathrm{n} / \mathrm{a}$ & $(0.13)$ & $\mathrm{n} / \mathrm{a}$ & $\mathrm{n} / \mathrm{a}$ & $\mathrm{n} / \mathrm{a}$ & $\mathrm{n} / \mathrm{a}$ & $\mathrm{n} / \mathrm{a}$ & $\mathrm{n} / \mathrm{a}$ & $\mathrm{n} / \mathrm{a}$ \\
\hline Tourism Geography & $\mathrm{n} / \mathrm{c}$ & $\mathrm{n} / \mathrm{c}$ & $\mathrm{n} / \mathrm{c}$ & $\mathbf{0 . 7 3}$ & $\mathrm{n} / \mathrm{c}$ & 0.08 & $\mathrm{n} / \mathrm{c}$ & $\mathrm{n} / \mathrm{c}$ & $\mathrm{n} / \mathrm{a}$ & $\mathrm{n} / \mathrm{a}$ \\
\hline Hospitality and Customer Service & $\mathbf{0 . 8 7}$ & $\mathrm{n} / \mathrm{c}$ & $(1.00)$ & $(0.16)$ & $(0.25)$ & 0.04 & $\mathrm{n} / \mathrm{c}$ & $\mathrm{n} / \mathrm{c}$ & $\mathrm{n} / \mathrm{a}$ & $\mathrm{n} / \mathrm{a}$ \\
\hline Hotel Department Management & 0.65 & $\mathrm{n} / \mathrm{a}$ & $\mathbf{1 . 0 0}$ & $\mathrm{n} / \mathrm{c}$ & $\mathrm{n} / \mathrm{c}$ & $\mathrm{n} / \mathrm{c}$ & $\mathrm{n} / \mathrm{a}$ & $\mathrm{n} / \mathrm{a}$ & $\mathrm{n} / \mathrm{a}$ & $\mathrm{n} / \mathrm{a}$ \\
\hline $\begin{array}{l}\mathrm{n} / \mathrm{c}=\text { date is uncorrelated } \\
\text { n/a = no student has attended the course in the given rank of attendance }\end{array}$ & & & & & & \\
\hline
\end{tabular}

It could be inferred that the correlation at attendance level (90\%-100) per academic performance is rather low and only is in place for two study courses: Professional terminology (German / French / Spanish / Russian) 1 and Professional terminology (German / French / Spanish / Russian) 2. Students in the study courses Professional terminology (German / French / Spanish / Russian) and English have been divided into small groups. Higher attendance - higher 
academic performance might be explained by the relatively low number of students in groups, thus motivating students and providing regular focus and feedback.

At attendance $80 \%-90 \%$ the correlation is rather strong in 4 study courses $(\mathrm{r}=0.68, \mathrm{r}=0.93, \mathrm{r}=1, \mathrm{r}=1)$. The majority of study courses correlate with academic performance (in 3-grade category) at attendance level 30\%-40\%. This correlation analysis shows more in-depth insight into attendance and academic performance.

\section{Conclusions}

The average attendance per all study courses in the years 2018 and 2019 stands at $47.05 \%$. There could be several reasons, which should be analysed in depth in next researches. University policy towards attendance is one of the milestones related to academic performance.

Per midterm exam students who attended $0 \%-10 \%$ classes positive assessment gained $20.5 \%$ students, negative assessment $79.5 \%$ students. 29 out of 30 students who attended $90 \%-100 \%$ classes gained positive assessment. In case of midterm exam all students who attend at least $70 \%$ classes gain positive assessment.

Per exam students who attended $0 \%-10 \%$ classes positive assessment gained $13 \%$, negative assessment gained $86 \%$ students. 26 out of 29 students who attended 90\%-100\% classes gained positive assessment.

The midterm exam has motivating character, with the goal of learning, finding mistakes, getting feedback, that's the reasons for so many passes. The exam, on the other hand, has stricter, more specific requirements.

The highest average attendance among study courses is for course English 2, where the observed average attendance reached $81.97 \%$. According to the opinion of representative of Higher Education Export Association, the motivation to attend classes can be affected by the overall number of students in the class.

In case of exam only 1 student out of 891 have gained negative assessment “ 3 ". In case of final assessment all students have passed at attendance level 90\%$100 \%$.

The results of the current research show Pearson correlation between the total attendance and the total academic performance $\mathrm{r}=0.47$ for midterm exam grade, $\mathrm{r}=0.42$ for exam grade and $\mathrm{r}=0.40$ for final assessment.

Correlation among academic performance in 14 study courses and attendance levels are concluded. At 90\%-100\% attendance level correlation exists $r=0.32$; $r=0.13$ for midterm grade, $r=0.21$ for exam grade and $r=0.20$ for final assessment.

At $80 \%-90 \%$ attendance level correlation exists $\mathrm{r}=0.68$ for midterm grade, $r=0.93$ and $r=1.00$ for exam grade and $r=1$ for final assessment. 
At $50-60 \%$ attendance level correlation exists $r=1$ for midterm grade, $r=1.00$ for exam grade and $r=1.00$; $r=0.60$ for final assessment.

At $30-40 \%$ attendance level correlation exists $r=0.68 ; r=1 ; r=0.96 ; r=0.66$ for midterm grade, $r=0.78 ; r=0.51 ; r=0.70$ for exam grade and $r=0.62 ; r=0.87 ; r=0.61$; $\mathrm{r}=0.73$ for final assessment.

At $10-20 \%$ attendance level correlation exists $r=0.89 ; r=0.76 ; r=1.00 ; r=0.65$ for midterm grade, $r=0.71 ; r=0.50$ for exam grade and $r=0.77 ; r=0.50 ; r=0.50$ for final assessment. At $0-10 \%$ attendance level correlation exists $r=0.65 ; \mathrm{r}=0.65$; $r=0.87$ for midterm grade, $r=0.72 ; r=0.57$ for exam grade and $r=0.87 ; r=0.65$ for final assessment.

At $40 \%-50 \%$ and $70 \%-80 \%$ attendance level positive correlation do not exists at all.

It can be concluded strong correlation (assuming that strong correlation $r \geq 0,50$ ) exists more often among class attendance per study courses and academic performance at attendance level $0 \%-40 \%$. The high correlation reflects the impact of a class attendance on positive academic performance without specification what grade is achieved.

It indicates, that only partly international students see class attendance as a value in their academic performance. In Higher Education Export Association believes that motivation to get better grades and more to attend lessons appears in later study years.

It has to be taken into account by the educators for the purpose of designing a meaningful, interesting and stimulating study course promoting the achievement of higher grades.

Authors suggest smaller student groups per study courses as it can lead to better attendance and therefore better academic performance.

Further research should analyse students gaining the highest and lowest overall marks in order to find if there is a difference in their attendance. Further research should individualise student profiles and their background. While generalizations have been made, it does not appear that attendance is a predictor of performance on an individual basis.

Further research should also analyse the part-time employment of students in order to address the ways paid employment might affect attendance and academic performance.

\section{References}

Auers, D., \& Gubins, S. (2016). Augstākās izglītības eksporta ekonomiskā nozīme un ietekme Latvijā, Politikais pārskats. Domnīca Certus. Pieejams http://certusdomnica.lv/agenda/ augstakas-izglitibas-eksporta-ekonomiska-nozime-un-ietekme-latvija/ 
SOCIETY. INTEGRATION. EDUCATION

Proceedings of the International Scientific Conference. Volume VI, May $22^{\text {th }}-23^{\text {th }}, 2020.578-594$

Bijsmans, P., \& Schakel, A.H. (2018). The impact of attendance on first-year study success in problem-based learning. Higher Education, 76(5), 865-881. DOI: 10.1007/s10734-0180243-4

Brennan, A., Sharma, A., \& Munguia, P. (2019). Diversity of Online Behaviours Associated with Physical Attendance in Lectures. Journal of Learning Analytics, 6(1), 34-53. DOI: https://doi.org/10.18608/jla.2019.61.3

Credé, M., Roch, S.G., \& Kieszczynka, U.M. (2010). Class Attendance in College: A MetaAnalytic Review of the Relationship of Class Attendance With Grades and Student Characteristics. Review of Educational Research, 80(2), 272-295.

DOI: https://doi.org/10.3102/0034654310362998

Creswell, J.W. (2005). Educational Research. Planning, Conducting, and Evaluating Quantitative and Qualitative Research (second edition). Pearson Education, Inc., USA.

Dolnicar, S., Kaiser, S., \& Matus, K. (2009). Can Australian universities take measures to increase the lecture attendance of marketing students? Journal of Marketing Education, 31(3), 203-211. DOI: http://doi.org/10.1177/0273475309345202

Education at a Glance 2012. (2012). OECD. Highlights. DOI: https://doi.org/10.1787/ eag_highlights-2012-en

Edwards, M.R., \& Clinton, M.E. (2019). A study exploring the impact of lecture capture availability and lecture capture usage on student attendance and attainment. Higher Education, 77, 403. DOI: https://doi.org/10.1007/s10734-018-0275-9

Field, S. (2012). Understanding attendance and non-attendance motivation amongst first year undergraduate students. In: Proceedings of the SOLSTICE \& CLTR Conference. Edge Hill University. Retrieved from: http://eshare.edgehill.ac.uk/1715/1/Day_2_Session_4_ Will_this_Come_Up_in_the_Exam.pdf

Freeman, S., Eddy, S L., \& McDonough, M., (2014). Active learning increases student performance in science, engineering, and mathematics. Proceedings of the National Academy of Sciences, 111(23), 8410-8415.

DOI: http://doi.org/10.1073/pnas.1319030111

Humphrey, R. (2001). Working is a class issue. The Times Higher Education Supplement. Retrieved from https://www.timeshighereducation.com/news/working-is-a-classissue/156672.article

Immigration Law. Adoption 31.10.2002. Published: Latvijas Vēstnesis, 169, 20.11.2002. Pieejams https://likumi.lv/ta/id/68522

Irwin, N., Burnett, K.M., \& McCarron, P.A. (2018). Association between attendance and overall academic performance on a module within a professional pharmacy degree. Currents in Pharmacy Teaching and Learning, 10(3), 396-401.

DOI: https://doi.org/10.1016/j.cptl.2017.11.008

Jansen, E.P.W.A., \& Suhre, C.J.M. (2010). The effect of secondary school study skills preparation on first-year university achievement. Educational Studies, 36(5), 569-580. DOI: https://doi.org/10.1080/03055691003729070

Jennifer, A., \& Phillips, P.B.(2015). Replacing traditional live lectures with online learning modules: Effects on learning and student perceptions. Currents in Pharmacy Teaching and Learning, 7(6),738-744. DOI: https://doi.org/10.1016/j.cptl.2015.08.009

Kassarnig, V., Bjerre-Nielsen, A., \& Mones, E. (2017). Class attendance, peer similarity, and academic performance in a large field study. PLOS ONE, 12(11).

DOI: https://doi.org/10.1371/journal.pone.0187078 
Kelly, G.E. (2012). Lecture attendance rates at university and related factors. Journal of Further and Higher Education, 36(1), 17-40.

DOI: http://doi.org/10.1080/0309877X.2011.596196

Lan, S-W. (2018). Exploring the Academic English Socialization of International Graduate Students in Taiwan. Journal of International Students, 8(4)1748-1763.

DOI: 10.5281/zenodo.1468082

Lukkarinen, A., Koivukangas, P., \& Seppälä, T. (2016). Relationship between Class Attendance and Student Performance. Procedia - Social and Behavioral Sciences, 228, 341-347. DOI: https://doi.org/10.1016/j.sbspro.2016.07.051

Masevičiūtè, K., Šaukeckienè, V., \& Ozolinčiūtè, E. (2018). Combining studies and paid job, Thematic review. The EUROSTUDENT VI project. Retrieved from https://www.eurostudent.eu/download_files/documents/TR_paid_jobs.pdf

Massingham, P., \& Herrington, T. (2006). Does Attendance Matter? An Examination of Student Attitudes, Participation, Performance and Attendance. Journal of University Teaching \& Learning Practice, 3(2). DOI: https://ro.uow.edu.au/jutlp/vol3/iss2/3

McInnins, C., \& Hartlet, R.(2002). Managing study and work: the impact of full-time study and paid work on the undergraduate experiences in Australian universities. Canberra, Australian Capital Territory: DEST.

Morris, N.P., Swinnerton, B., \& Coop, T. (2019). Lecture recordings to support learning: A contested space between students and teachers. Computers \& Education, 140.

DOI: https://doi.org/10.1016/j.compedu.2019.103604

Neyt, B., Omey, E., \& Verhaest, D. (2017). Does Student Work Really Affect Educational Outcomes? A Review of the Literature. Discussion paper series. Institute of Labor Economics, DP No. 11023. Retrieved from http://ftp.iza.org/dp11023.pdf

Nyamapfene, A. (2010). Does class attendance still matter? Engineering Education, 5(1), 6474. DOI: https://doi.org/10.11120/ened.2010.05010064

Paisey, C., \& Paisey, N.J. (2004). Student attendance in an accounting module - reasons for non-attendance and the effect on academic achievement at a Scottish university.

Accounting Education, 13(1), 39-53.

DOI: https://doi.org/10.1080/0963928042000310788

Pārskats par Latvijas augstāko izglìtību 2018. gadā. (2019). Izglīīibas un zinātnes ministrija, Galvenie statistikas dati. Pieejams https://www.izm.gov.lv/images/statistika/augst_ izgl/Augstakas_izglitibas_LV_parskats_2018.pdf

Pārskats par Latvijas augstāko izglītību 2017. gadāa. (2018). Izglītības un zinātnes ministrija, Galvenie statistikas dati. Pieejams https://www.izm.gov.lv/images/statistika/augst_ izgl/AII_2017_parskats.pdf

Pārskats par Latvijas augstāko izglītību 2016. gadā. (2017). Izglīīibas un zinātnes ministrija, Galvenie statistikas dati. Pieejams https://www.izm.gov.lv/images/izglitiba_augst/

Parskats_augstaka_izglitiba_2016.pdf

Regulations on the second level professional higher education state standard. (2014). Cabinet of Ministers Regulation No.512. Adoption 26.08.2014., Published: Latvijas Vēstnesis, 179, 11.09.2014. Pieejams https://likumi.lv/ta/id/268761-noteikumi-par-otra-limenaprofesionalas-augstakas-izglitibas-valsts-standartu

Slavio, J. (2017). Microsoft Excel: Advanced Microsoft Excel Data Analysis for Business. Publisher: Create Space Independent Publishing Platform.

Schmuliana, A., \& Coetzee, S. (2011). Class absenteeism: reasons for non-attendance and the effect on academic performance. Accounting Research Journal, 24, 178-194.

DOI: https://doi.org/10.1108/10309611111163718 
Schnee, D., Ward, T., \& Philips, E. (2019). Effect of Live Attendance and Video Capture Viewing on Student Examination Performance. American journal of pharmaceutical education. 83(6), 6897. DOI: 10.5688/ajpe6897

Thatcher, A., Fridjhon, P., \& Cockcroft, K. (2007). The relationship between lecture attendance and academic performance in an undergraduate psychology class. South African Journal of Psychology, 37(3), 656-660. DOI: https://doi.org/10.1177/008124630703700316

Turiba University. (2019). Internal documents of Turiba University.

Vajoczki, S., Watt, S., \& Marquis, N. (2011). Students Approach to Learning and their Use of Lecture Capture. Journal of Educational Multimedia and Hypermedia, 20.

Retrieved from https:/www.researchgate.net/publication/277825918_Students_ Approach_to_Learning_and_their_Use_of_Lecture_Capture

Walker, R., Voce, J., \& Nicholls, J. (2014). 2014 Survey of Technology Enhanced Learning for higher education in the UK. UCISA report: Oxford. Retrieved from https://www. academia.edu/21424616/2014_Survey_of_Technology_Enhanced_Learning_for_higher _education_in_the_UK

Westerman, J.W., Perez-Batres, L.A., \& Coffey, B.S. (2011). The relationship between undergraduate attendance and performance revisited: Alignment of student and instructor goals. Decision Sciences Journal of Innovative Education, 9(1), 49-67.

DOI: https://doi.org/10.1111/j.1540-4609.2010.00294.x

Yanbarisova, D.M. (2015). The Effects of Student Employment on Academic Performance in Tatarstan Higher Education Institutions. Russian Education \& Society, 57(6), 459-482, DOI: $10.1080 / 10609393.2015 .1096138$ 